\title{
ZONGULDAK İLİNDE NÜFUSUN GELIŞiMİ VE DAĞILIŞI
}

Development and Ditrubition of the Population in the City of Zonguldak

Yard..Doç.Dr. Taşkın DENIZZ

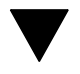

\section{Özet}

Araştırmanın amacı, demografik açıdan çeşitli özellikleri ile Zonguldak il nüfusunun başlıca özelliklerini ortaya koymak ve yapllacak olan sonraki çalışma ve yatırım planlarına katkıda bulunabilmektir. Bu kapsamda çalışmada cumhuriyetin ilanından sonra gerçekleştirilen nüfus sayımlarına göre Zonguldak il nüfusunda gerçekleşen zamansal değişimlere, nüfus artış hızına, kadın ve erkek nüfusa, cinsiyet oranına ve nüfusun yaş gruplarına göre dağllımına değinilmiştir.

Tarihsel süreç içerisinde Zonguldak'ın, ekonomik ve idari bakımdan gelişmesine paralel olarak nüfusu da artış göstermiştir. Ancak toplam nüfus açısından değerlendirildiğinde 1990'lı yıllara kadar Türkiye'nin en fazla nüfusuna sahip illerinden biri iken Bartın ve Karabük illerinin ayrllması ile nüfusunun yaklaşı \% 40'ını kaybetmiştir. Zonguldak, Türkiye Taş Kömürleri (TTK) 'nin -küçülmeye başlamasına bağlı olarak-işçi alımını azaltması ve ortaya çıkan geçim sıkıntısı, işsizlik, yoğun emekli nüfus gibi sosyo-ekonomik nedenlerden dolayı günümüzde nüfusu azalan illerden biri durumuna düşmüşı̈̈r. Bu sebeplerle insanların çoğu iş umudu ile özellikle Bursa ve İstanbul gibi illere göç etmektedir. Kadın ve erkek nüfus ise dönemin sosyo-ekonomik şartlarına paralel şekilde değişim göstermiştir. Ülkemizde kadın nüfusun fazla olduğu illerden biridir. Çalışma çağındaki nüfusta yoğunluk vardır.

Anahtar Kelimeler: Zonguldak, Nüfus Artışı, Nüfus Artış Hızı, Cinsiyet Oranı, Erkek - Kadın Nüfus. 


\begin{abstract}
The purpose of this study was to determine the main features of Zonguldak province with its various demographic characteristics and to contribute to the following studies and investment plans. In this sense, this study dealt with timewise changes occurring in the population of Zonguldak after proclamation of the republic, and also population growth rate, female and male population, sex ratio and the distribution of population according to age groups.

During the historical process, the population of Zonguldak increased in parallel with the economic and managerial developments. While Zonguldak was one of the most populated provinces of Turkey until 1990's in the aspect of total population, it lost its $40 \%$ of population with Karabuk and Bartin's separation. Today Zonguldak becomes one of the provinces of Turkey with a decreasing population because of the socio-economical problems such as decreasing number of workers employed by Turkish Coal Institute (TCI) - in parallel with the institution's becoming smaller - financial difficulties of workers, and unemployment, dense population of retired people. Therefore, many people from Zonguldak expecting to be employed move to provinces such as Bursa and Istanbul. Female and male population has also changed in accordance with the socio-economical conditions of the current era. Zonguldak is now one of the provinces in which female population is of high level. Working age population is dense in Zonguldak.
\end{abstract}

Key Words: Zonguldak, Population Growth, Popülation Growth Rate, Sex Ratio, Male - Female Popülation. 


\section{Giriş}

İktisat biliminde ekonomik büyümenin temel unsurları arasında nüfus mutlaka ifade edilir. Nüfusun miktarı, eğitim durumu, kültürel ve teknik seviyesi ve sosyo-ekonomik nitelikleri, ekonomik kalkınmanın göz ardı edilemeyecek unsurları arasında yer alır. $\mathrm{Bu}$ sebeple nüfusu incelemeden sosyal ve ekonomik sorunlara isabetli teşhis koymak ve çözüm yolları bulmak mümkün değildir. Bu açıdan ele alındığında nüfus, sosyo-ekonomik planlamada önemli bir yer işgal eder (Tandoğan, 1998:2).

20. yüzyıl siyasi, sosyo-ekonomik, bilimsel, teknolojik ve demografik açıdan önemli gelişmelere sahne olmuştur. Yüzyılın başında dünya nüfusu 1,6 milyar iken, yüzyılın sonunda bu rakam 6,1 milyara ulaşmıştır. Şehirlerde yaşayan insan sayısı \% 15'ten \% 55'lere çıkmıştır. Ülkemizde ise cumhuriyetin ilk yıllarında 13 milyon civarında olan nüfus, yüzyılın sonunda 75 milyona ve şehirleşme oranı da \% 16'dan \% 75'lere yükselmiştir. Nüfus artışları, yüzyılın özellikle ikinci yarısında ekonomik, teknolojik ve toplumsal nedenlerle hızlı bir artış göstermiştir. Nüfustaki bu hızlı artış, sosyo-ekonomik değişimlerin yaşanmasına neden olarak beraberinde göç kavramını ve kentleşme sürecini getirmiştir. Kırsal kesimde geçimini sağlayamayanlar ve üretim dışı kalan genç işgücü, yeni geçim kaynakları bulmak üzere önce yakınındaki şehirlere ve daha sonra da ulaşabildiği büyük şehirlere göç etmeye başlamıştır (Karakuyu, 2007:139). Bu kapsamda Türkiye açısından bir durum değerlendirmesi yapılacak olunursa görülecektir ki; kır yerleşmeleri çeşitli yoksunluklara büründürülürken, kent yerleşmeleri ise birçok varlıkla canlandırılmaktadır. Örneğin; kentlerin çekicilikleri arasında yer alan iş imkânlarının fazla olması ve yüksek ücretler ile birlikte kültür, eğitim ve sağlık alanlarındaki olanaklardan köyde yaşayanların mahrum kalması gibi faktörler, Türkiye'nin yaşadığı göç olgusuna önemli oranda kaynaklık etmiştir (Kaya, 2013:5). Nitekim Zonguldak ili de özellikle 1950'lerden sonra madenciliğe bağlı olarak önemli miktarda iç göç almış, bu durum hızlı ama kontrolsüz bir demografik yapının ve kentleşme sürecinin ortaya çıkmasına neden olmuştur. Ancak göç süreci 1990’lı yıllardan itibaren tersine dönmüş ve Zonguldak göç veren illerden birine dönüşmüştür.

Batı Karadeniz Bölümü'nde yer alan Zonguldak ili doğuda Bartın, güneydoğuda Karabük, güneyde Bolu, batıda Düzce ve kuzeyde Karadeniz ile çevrilidir. $41^{\circ}-41^{\circ} 48$ dakika kuzey enlemi ile $31^{\circ} 10$ dakika - $32^{\circ} 50$ dakika doğu boylamı arasında yer almaktadır. Merkezi ile birlikte 8 ilçeden oluşan il idari alanının toplam yüzölçümü $3.309 \mathrm{~km}^{2}$ 'dir (Karakuyu, 2007:139; İlhan ve Koçal, 1986:26). Sahip olduğu yüzölçümü ile Türkiye topraklarının \%o 4.2'sini kaplamaktadır. 1990'ların başında Karadeniz bölgesinin en geniş yüzölçümüne $\left(8.629 \mathrm{~km}^{2}\right)$ ve en fazla nüfusuna (1.073.560, 1991 yılında) sahip illerinden biri iken, 1991 yılında Bartın ve 1995 yılında Karabük ilçelerinin il olarak ayrılması ile hem yüzölçümü hem de nüfusu önemli ölçüde azalmıştır.

Zonguldak'ın Karadeniz sahil uzunluğu yaklaşık 85 km'dir. İl bünyesinde 31 belediye ve 365 köy bulunmaktadır. Uzaklığı Ankara'ya 270 km ve İstanbul'a 360 km'dir (Yeni ve diğerleri, 2013:46). İl merkezi temel alındığında sahil boyunca batıya doğru gidildiğinde Ereğli, Alaplı ve Akçakoca üzerinden İ́stanbul'a; doğuya doğru Bartın, Kastamonu ve Sinop üzerinden Doğu Karadeniz illerine; güneye doğru ise Devrek üzerinden Ankara'ya ulaşım sağlanmaktadır. 
Şekil 1: Zonguldak İli Lokasyon Haritası

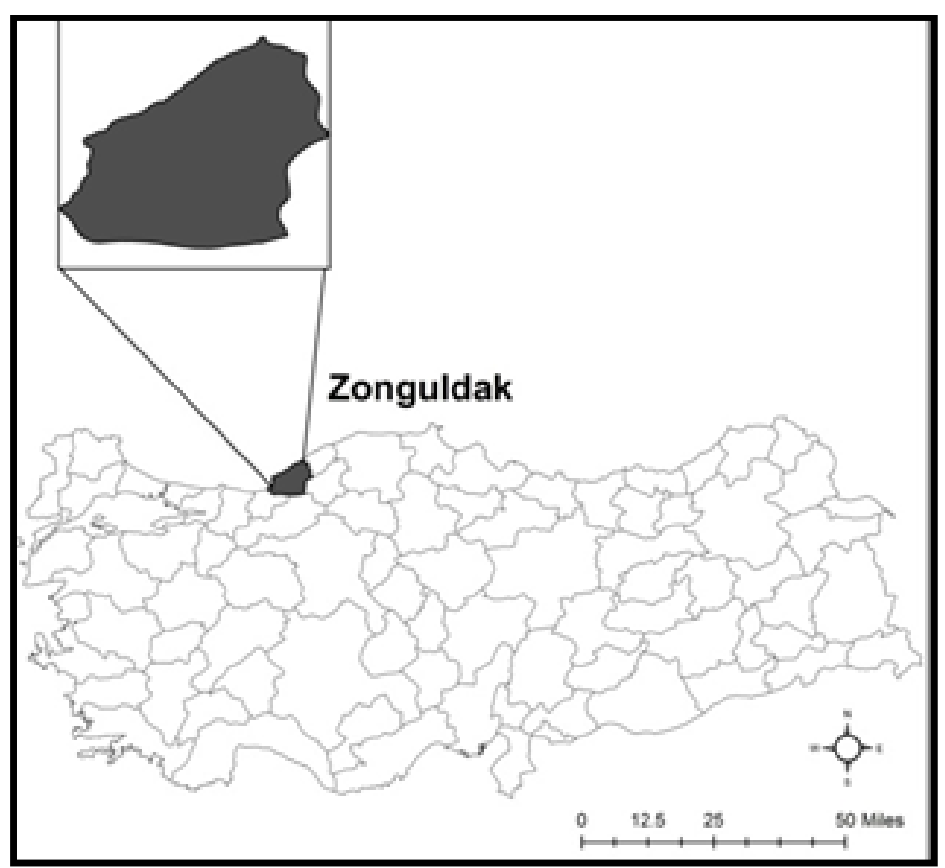

Zonguldak ili genelinde, gerek yaşam koşullarına gerekse de ekonomik faaliyetlere daha uygun olması sebebi ile nüfusun kıyı kesimde dağların kuzey yamaçlarında, iç kesimlerde ise vadi içlerinde ve ova özelliği taşıyan düz sahalarda toplandığı görülmektedir. Yer şekillerinin dağlık ve engebeli olması nedeni ile il merkezi dâhil olmak üzere ilin genelinde dağınık yerleşme ön plandadır.

İlin ekonomik yapısını belirleyen unsurlar taş kömürü, demir-çelik sanayi, çimento sanayi, orman ürünleri ve kâğıt sanayidir. Zonguldak ilinin ekonomik hayatında madenin önemi Osmanlı döneminde olduğu gibi, Cumhuriyet'in ilk yıllarında da devam etmiştir. Nitekim 1927 nüfus sayımına göre sanayi sektörleri arasında en fazla istihdam yaratanı, madencilik olmuştur (Genç, 2010:138). Bu durum daha sonraki yıllarda da artarak devam etmiş̧ir.

Demiryolu ve limanları sayesinde kısa sürede bir sanayi şehrine dönüşen Zonguldak'a, iş gücü açığının da etkisi ile 1950'lerden sonra yoğun işçi göçü yaşanmıştır. $\mathrm{Bu}$ durum Anadolu'nun değişik kesimlerden gelen kültürlerin harmanlaştığı hızlı bir kentleşme sürecini ortaya çıkarmıştır. Türkiye Taş Kömürleri işletmesi (TTK), Ereğli DemirÇelik Fabrikası (ERDEMİR), Çaycuma Seka Kâğıt Fabrikası, Filyos Ateş Tuğla Fabrikası, Çatalağzı Termik Elektrik Santrali (ÇATES), Zonguldak Eren Termik Santrali (ZETES) ve özelleştirilen taş kömürü ocak işletmeleri, ilin en önemli sanayi tesisleridir. Devrek, Çaycuma ve Gökçebey'de çok sayıda Kereste ve Ambalaj; Filyos, Ereğli ve Çaycuma'da Çimento ve Tuğla; Alaplı'da Dinarsu sanayi tesisi bulunmaktadır. Diğer önemli sanayi 
tesisleri bisküvi, konserve, yağ ve un fabrikalarıdır. Zonguldak'ta çıkartılan en önemli madenler taş kömürü, linyit (Ereğli, Davutlar ve Çamalı), demir (Alaplı Kangalar ve Merv, Devrek Kodamanoğlu), alüminyum (Zonguldak Kokaksu ve Sapanlıdere), manganez (Ereğli Gülünç ve Kızlar dereleri vadileri boyunca, Devrek Yiyicitepe), boksit (Merkez ilçe Hayat Köyü) ve dolomit (Alaplı ve Ereğli)'tir. Zonguldak il merkezinde TTK'ya ait Zonguldak Limanı, Çatalağzı Muslu mevkiinde Eren Enerji A.Ş.'ye ait Eren Limanı olmak üzere iki adet liman ve üç adet balıkçı barınağı (Filyos, Kilimli ve Kozlu'da) mevcuttur. Ayrıca, işletme izni aşamasında Kilimli ilçesinde 1 adet Tersane ve kiralama aşamasında 1 adet Gemi Geri Dönüşüm yeri mevcuttur. Ereğli ilçesinde TTK'ya ait bir liman ve ERDEMIR Limanı bulunmaktadır. Bu limanların il ekonomisindeki ve taşımacılıktaki önemi büyüktür. Bunların içinde en önemlisi, Karadeniz Bölgesinin en önemli ve işlek limanlarından biri olan ve toplam nakliyenin \%75'inin gerçekleştirildiği Ereğli Limanı'dır (Zonguldak Valiliği, 2011:511).

\section{Zonguldak İl Nüfusunun Gelişimi}

Nüfus, hareket halinde her an ve durmadan değişen bir sosyal unsurdur. Nitekim herhangi bir sahada insanın çevre üzerindeki etki derecesi, öncelikle nüfus miktarı ve yoğunluğuna bağlı olmakla beraber nüfusun sosyo-ekonomik, kültürel ve teknik seviyesi de bu açıdan önemlidir (Tanoğlu, 1966:28-29). Nüfus verileri zamana ve mekâna göre değişim gösterir ve herkes için farklı anlamlar taşır. Yöneticiler, politikacılar, planlamacılar, yatırımcılar ve bilim insanları için nüfus verileri önem arz eder (Şahin, 2007:14-15). Aynı zamanda doğurganlık, bağımlılık oranı ve göçe kaynaklık etme gibi özelliklere de sahiptir. $\mathrm{Bu}$ nitelikleri ile nüfus, belli bir sayım gününde sınırları belirli bir yerleşim birimindeki toplam insan sayısını ifade eder. Bir yerleşmenin nüfus olguları ile ekonomik olguları arasında yakın ilişki vardır (Doğanay, 1991:2). Türkiye'de bu ilişkiyi temsil eden illerin başında Zonguldak gelmektedir.

EKİ (şimdiki adı TTK) ve Karabük Demir Çelik Fabrikası'nın ihtiyaç duyduğu iş gücü açığının kapanması amacı ile özellikle 1950'li yıllardan sonra Anadolu'nun çoğu ilinden işçi göçü alınmasına bağlı olarak Zonguldak, farklı kültürel özelliklere sahip nüfusu barındırmaktadır. İl, 1950'li yıllardan itibaren bir sanayi şehri kimliği kazanarak çevresi için bir çekim merkezine dönüşmüştür. Sanayileşmeye bağlı hızlı nüfus artışı aynı zamanda kentleşme sürecini de olumlu yönde tetiklemiştir. Örneğin 1960'l yıllardan sonra Kilimli, Karadon ve Gelik mevkiinde maden işçilerinin yaşamlarını kolaylaştırmak amacı ile çok sayıda lojman inşa edilmiş, işçi ve mühendis lokalleri açılmış, sinemalar faaliyete girmiş ve balo tarzı özel geceler düzenlenmiştir. Yaşı itibari ile böylesine bir dönemi iyi bilen büyükler, o dönemleri anlatırken özlem duyduklarını dile getirmektedirler.

1950'lilerden itibaren Zonguldak ilinin sanayisine bağlı olarak nüfus toplamaya başlaması, kentleşme ile sanayi arasındaki ilişkiyi ve artan kentsel nüfusun kırsal nüfus üzerindeki etkisini ortaya koyması açısından önem arz etmiştir. Batıda Ereğli ilçesinden başlamak üzere doğuya doğru sırası ile Kozlu, Zonguldak Merkez, Kilimli, Çatalağzı, Filyos, Kokaksu, Bartın ve Amasra yerleşmeleri boyunca bir kıyı sanayi şeridi oluşmuştur (Emiroğlu, 1966: 149-150). Böylesine bir sanayi kuşağını oluşturan temel unsurlar ise taşkömürü ve bağlı sanayi kolları ile limanların varlığı olmuştur. Zonguldak ilinin nüfus 
konusundaki bu çekici üstünlüğü o dönem için Batı Karadeniz Bölümü’nden İstanbul'a olan göçleri yavaşlatmıştır.

1950'li y1llardan itibaren Zonguldak'ta taşkömürü ve demir-çeliğe bağlı sanayinin ortaya çıkardığı istihdam alanları, özellikle iç kesimlerdeki vadilerde ve düzlük sahalarda yaşayan yerli halka pek çekici gelememiştir. Bunun temel nedenleri, sanayinin hinterlandı çok geniş olmayan bir sahada kurulması, iç kesimler ile kıyı şeridi arasındaki ulaşımın gelişmemiş olması ve tarımsal faaliyetlerinin kendilerine yetebileceklerine inanmaları etkili olmuştur. Bu durum Anadolu'nun pek çok ilinden Zonguldak'a iş̧i göçünü hızlandırmıştır.

1960'lı yılların başından itibaren ise Avrupa ülkelerine gerçekleşen işçi göçünün sanayide çalışmayı ön plana çıkarması ildeki kırsal nüfusun görüşlerini değiştirmiş̧; Eflani, Ulus, Kurucaşile, Gökçebey ve Devrek'e bağlı kırsal yerleşmelerden sanayi kuruluşlarının bulunduğu kent merkezlerine doğru göçleri artırmıştır. Örneğin, 1940 - 1965 yılları arasında Zonguldak kent merkezindeki kır nüfusu \% 40 artarken, şehir nüfusu ise \% 200 artış göstermiştir (Emiroğlu, 1966:157).

Zonguldak, Türkiye Cumhuriyeti Devleti'nin ilk ili olma özelliğine sahiptir. İle ilişkin doğru ve güvenilir nüfus verileri, aynı zamanda Türkiye Cumhuriyeti Devleti’nin de ilk nüfus sayımı olan 1927 Nüfus Sayımı'na aittir. Bu tarihten önceki nüfus verilerinin kısıtlı olması, nüfus coğrafyasına yönelik değerlendirmeleri sınırlandırdığı için tatmin edici değildir (Arıbaş, 2007:315). Bu nedenle il bazında nüfus özelliklerini 1927 yılından itibaren incelemeyi uygun bulduk. Araştırmada Zonguldak nüfusu ile ilgili tüm veriler, bu tarihten sonra gerçekleştirilen nüfus sayımlarının sonuçlarına dayanmaktadır. 2007 yılından itibaren ise ADNKS (Adrese Dayalı Nüfus Kayıt Sistemi) ile her yıl nüfusumuz hakkında ayrıntılı bilgi edinilebilmektedir. Bilindiği üzere söz konusu sayımlar, nüfusun yıllara göre toplam sayısı, çeşitli nüfus hareketleri, nüfusun sosyal ve ekonomik nitelikleri, kentsel ve kırsal nüfus miktarları gibi nüfusa ilişkin çeşitli özelliklerin tespit edilmesi (Doğanay, 1997: 151) ile bunların başta plânlama olmak üzere pek çok alanda kullanılmasına olanak sağlamaktadır (Zaman ve Coşkun, 2008: 266).

1927 Nüfus Sayımı'na göre Zonguldak ilinin nüfusu 267.990 olarak tespit edilmiştir. Nüfusun \% 47.2‘si erkeklerden ve \% 52.8`i ise kadınlardan oluşmaktaydı. 2013 Nüfus Sayımı'na göre ise il nüfusu 601.567'dir ve Türkiye'de 33. sırada yer almaktadır. Nüfusun $\% 49.3$ ‘ü erkeklerden ve $\% 50.7^{\prime}$ si kadınlardan meydana gelmektedir.

1927-2013 y1lları arasındaki 86 y1llık süre içerisinde nüfusta 335.567 (\% 224.47) artış meydana gelmiş̧ir. Ancak söz konusu devrede ülke genelindeki artışın yaklaşık 5.5 kat gerçekleştiği düşünülürse, araştırma sahasındaki büyümenin düşük seviyede kaldığ1 anlaşılmaktadır. Türkiye nüfusu içerisinde Zonguldak il nüfusunun payı 1927 yılında \% 1.96 iken bu pay 1950 y1lında \% 2.03, 1975 y1lında \% 2.07, 1990 yilında $\% 1.90,2000$ yllında \% 0.90 ve 2013 yılında \% 0.78 düzeyinde olmuştur. Artış sürekli gerçekleşmemiş, bilakis belli dönemlerde nüfus artış hızında olduğu gibi nüfus miktarında da azalmalar yaşanmıştır. Dikkat edilecek olunursa, sahip olunan pay, TTK'nın ihtişamlı günlerini yaşadığı 1950-1980 yılları arasında yüksek iken bu kurumun küçülmeye başlamasına bağlı verilen göçler ve Bartın - Karabük illerinin ayrılması sonucunda azalmaya başlamışıtır. Nüfus artış yüzdeleri ele alındığında 1927-2013 yılları arasında il nüfusunun en fazla 1927-1935 döneminde arttığı 
(\% 8.16) ve 2011 yılında ise azaldığ 1 (\% - 11.8) görülmektedir. Genel olarak nüfus artış hızı, Türkiye ortalamasından düşüktür. Nüfus miktarı açısından değerlendirildiğinde ise nüfusun en fazla 117.895 kişi ile 1975-1980 döneminde arttığı ve -7297 kişi ile de 2011 yılında azaldığı anlaşılmaktadır.

Tablo 1 ve Şekil 2 göz önüne alındığında, nüfusun genel seyri içerisinde 1927-1950, 1950-1990 ve 1990 sonrası olmak üzere üç dönemin belirginleştiği fark edilmektedir. 19271950 döneminde nüfus 158.694 kişi, 1950-1990 döneminde ise 646.876 kişi artış göstermiştir. Ancak 1990 sonrası ise diğer dönemlere göre azalma yönünde değişimin en net olduğu dönemdir. Bu dönem il nüfusu 471.993 kişi yani \% 43.96 azalmıştır. Bu durumun en önemli nedenleri 1991 yılında Bartın ve 1995 yılında Karabük ilçelerinin il olarak ayrılması, yaşanan küçülmeye bağlı olarak TTK'da çalışan işçi sayısının azalması, işçi göçü alımının durması ve işsiz genç nüfusun Bursa, İstanbul ve Kocaeli gibi illere göç etmeye başlamasıdır.

Tablo 1: Zonguldak İli ve Türkiye Geneli Nüfus Miktarı ve Nüfus Artış Hızları (1927 2013).

\begin{tabular}{|c|c|c|c|c|c|}
\hline $\begin{array}{l}\text { Sayım } \\
\text { Yılı }\end{array}$ & $\begin{array}{l}\text { Zonguldak } \\
\text { İli Nüfusu }\end{array}$ & $\begin{array}{l}\text { Nüfus } \\
\text { Artışı }\end{array}$ & $\begin{array}{l}\text { Nüfus } \\
\text { Artış Hızı } \\
(\%) \\
\end{array}$ & $\begin{array}{l}\text { Türkiye } \\
\text { Nüfusu }\end{array}$ & $\begin{array}{l}\text { Nüfus } \\
\text { Artış Hızı } \\
(\%) \\
\end{array}$ \\
\hline 1927 & 267.990 & ......... & .......... & 13.648 .270 & ........... \\
\hline 1935 & 322.108 & 54.180 & 8.16 & 16.158 .018 & 2.29 \\
\hline 1940 & 349.783 & 27.675 & 2.63 & 17.820 .950 & 2.05 \\
\hline 1945 & 383.481 & 33.698 & 2.38 & 18.790 .174 & 1.08 \\
\hline 1950 & 426.684 & 43.263 & 2.10 & 20.947 .188 & 2.29 \\
\hline 1955 & 491.147 & 64.463 & 1.63 & 24.064 .763 & 2.97 \\
\hline 1960 & 569.059 & 77.912 & 1.57 & 27.754 .820 & 3.06 \\
\hline 1965 & 650.191 & 81.132 & 1.71 & 31.391 .421 & 2.62 \\
\hline 1970 & 743.654 & 93.463 & 1.91 & 35.605 .176 & 2.68 \\
\hline 1975 & 836.617 & 92.963 & 1.73 & 40.347 .719 & 2.66 \\
\hline 1980 & 954.512 & 117.895 & 2.41 & 44.736 .957 & 2.17 \\
\hline 1985 & 1.044 .945 & 90.433 & 1.79 & 50.664 .458 & 2.64 \\
\hline 1990 & 1.073 .560 & 28.615 & 0.76 & 56.473 .035 & 2.29 \\
\hline 1997 & $612.722 *$ & $-460.838 *$ & $*$ & 62.865 .574 & 1.50 \\
\hline 2000 & 615.599 & 2.877 & 0.71 & 67.803 .927 & 2.20 \\
\hline 2007 & 615.890 & 291 & 3.02 & 70.586 .256 & 0.58 \\
\hline 2008 & 619.151 & 3261 & 0.53 & 71.517 .100 & 1.31 \\
\hline 2009 & 619.812 & 661 & 0.11 & 72.561 .312 & 1.45 \\
\hline 2010 & 619.703 & -109 & -0.1 & 73.722 .988 & 1.59 \\
\hline 2011 & 612.406 & -7.297 & -11.8 & 74.724 .269 & 1.35 \\
\hline 2012 & 606.527 & -5.879 & -9.6 & 75.627 .354 & 1.20 \\
\hline 2013 & 601.567 & -4.960 & -8.2 & 76.667 .864 & 1.37 \\
\hline
\end{tabular}

Kaynak: TÜİK Nüfus Sayım Verileri (*Bartın ve Karabük'ün ayrılması). 
Zonguldak'ta nüfus 1927-1935 döneminde 54.180 kişi artmış ve yıllık artış hızı \% 8.16 olarak gerçekleşmiştir. Söz konusu artış 1935-1940 arasında da devam etmiştir. Bu dönemde il nüfusu 27.675 kişi artmış ve yıllık artış hızı bir önceki döneme (1927-1935) göre azalarak \% 2.63 şeklinde gerçekleşmiştir. Bu durumun en büyük nedenleri; I. Dünya Savaş1 ve Kurtuluş Savaşı sebebi ile doğumların az buna karşın ölümlerin fazla gerçekleşmesi sonucunda bu yıllarda ebeveyn olma çağındaki nüfusun az olması ve İkinci Dünya Savaş tehlikesine bağlı olarak erkek nüfusun silâhaltına alınması sürecidir.

Şekil 2: Zonguldak İl Nüfusunun Gelişimi (1927 - 2013)

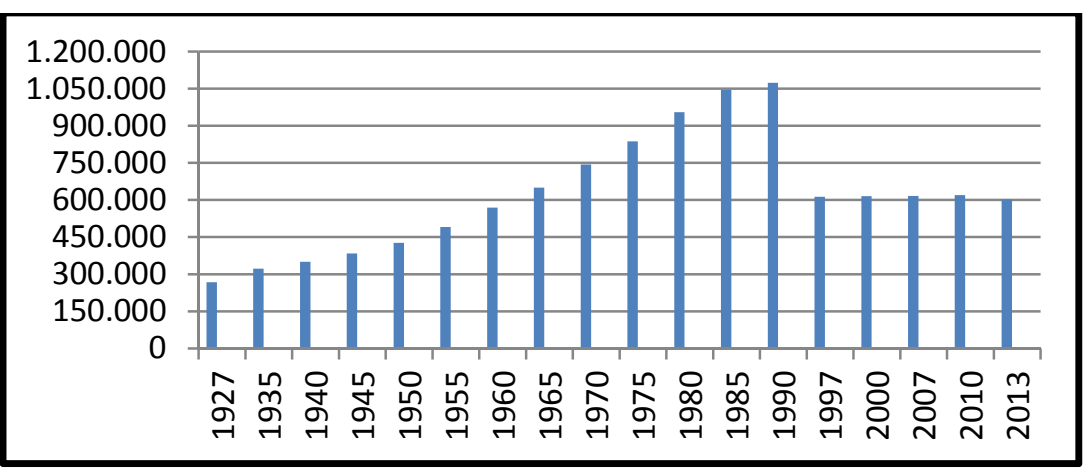

Kaynak: TÜİK Nüfus Sayım Verileri

1940-1945 ve 1945-1950 dönemlerinde, İkinci Dünya Savaşı’nın dolaylı etkileri nedeniyle il nüfusu az artmıştır. 1940-1945 periyodunda yıllık artış hızı \% 2.38'e inmiş olup ilin nüfusu ancak 33.698 kişi artarak 383.481 kişiye ulaşabilmiştir. Ülke genelinde olduğu gibi nüfustaki artışın az olma nedenleri; her ihtimale karşı savaşa hazırlık amacı ile yetişkin erkek nüfusun silâhaltında bulunması, uzun süreli askerlik görevi, doğumların azalması, açlık, kıtlık ve sefaletten dolayı sivil nüfusta görülen yüksek ölüm oranlarıdır. 1945-1950 devresinde nüfus, yıllık ortalama \% 2.10 oranında artarak, 426.684'e yükselmiştir. Bu durum üzerinde sıcak bir savaş durumunun ortadan kalkması, genel seferberliğin kaldırılması, askerlik süresinin normal sürelere indirilmesi, erkek nüfusun geri dönmesi, doğumların artması, sosyo-ekonomik ve sağlık alanlarında olumlu gelişmelerin ortaya çıkması ve ölüm oranlarının azalması etkili olmuştur.

1950-1955 dönemindeki nüfus artışı bir önceki döneme göre \% 1.63 artış göstermiş ve nüfus 491.147 kişiye çıkmıştır. Bu dönemdeki nüfus artışında EKİ (Ereğli Kömür İşletmeleri) ve KARDEMİR (Karabük Demir Çelik Fabrikası) tarafından gerçekleştirilen işçi alımları, sağlık hizmetlerinin yaygınlaşması ile ülke düzeyinde yaşanan kentleşme sürecine bağlı olarak kırsal yerleşmelerden şehir merkezlerine yaşanan iç göçler etkili olmuştur. Böylesine bir ortamda Zonguldak, çevre iller için istihdam özelliği nedeniyle çekici bir merkeze dönüşmüştür. Demiryolu ve limanların da etkisi ile kısa sürede hızla gelişen ve önemli bir sanayi şehri olan Zonguldak, Anadolu'nun değişik illerinden (özellikle Trabzon, 
Rize, Ordu, Artvin, Kars, Sivas, Giresun ve Kastamonu) aldığı işçi alımlarının etkisi ile hem nüfus artışını hem de kentleşme sürecini hızlandırmıştır (Harita 1).

Zonguldak'a işçi göçü veren illere baktığımızda bazı ortak özellikler göz önüne çıkmaktadır. Öncelikle adı geçen illerde büyük ölçekli sanayinin fazla olmaması, tarım dışı çalışabilir nüfusu eritememekte ve bu durum işsiz sayısını artırmaktadır (Yavuz, 1994:17). Diğer taraftan illerin hemen hepsi yer şekilleri, iklim ve ulaşım koşullarının olumsuzluğu nedeni ile sanayinin istendik düzeyde gelişmediği, tarım ve hayvancılığın ön planda olduğu yerleşmelerdir. Coğrafi konumları nedeni ile büyükşehirlere ulaşmada sıkıntı yaşamaktadırlar. Ayrıca geleneksel yaşam tarzına bağlı olarak genç yaşta evliliğin ve doğurganlığın yüksek olması nedeni ile evli genç nüfus oranı fazladır (Sönmez, 2010:47). Bu durum söz konusu şehirlerde işsizliğin önemli bir sorun olmasına bağlı olarak geçim sıkıntısı yaşanmasına sebep olmaktadır. Son olarak sosyal ve kültürel hizmetlerin yetersizliği de yaşam koşullarını zorlaştırmaktadır. Böylece bu illerden Zonguldak gibi sanayinin geliştiği illere yönelik göç olgusu ortaya çıkmaktadır.

Harita 1: Zonguldak İli’ne Yoğun İşçi Göçü Veren İller

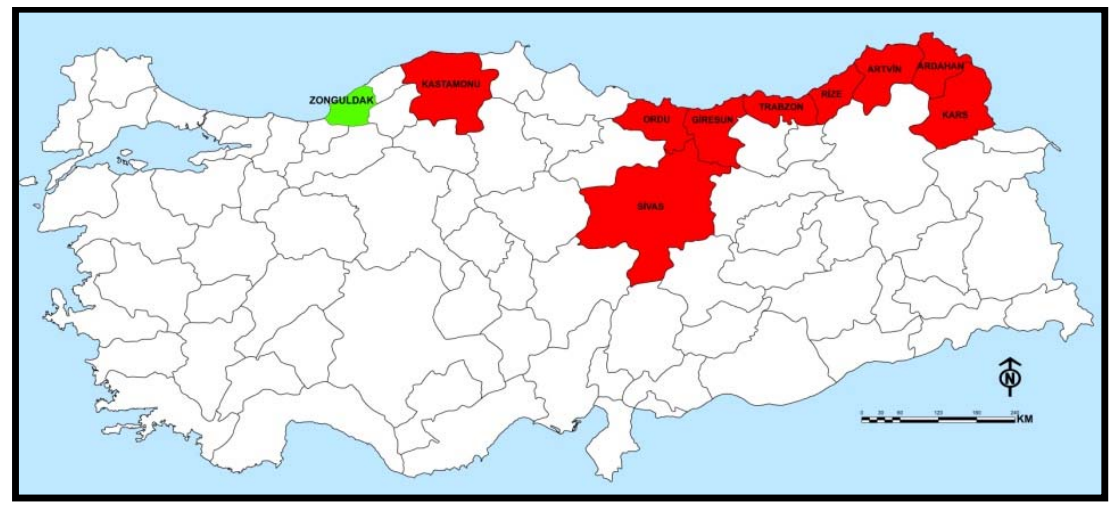

İlin toplam nüfusu 1955-1960 döneminde y1llık ortalama

$\% 1.57$ artarak 569.059 kişiye ulaşmıştır. Bu artışta ülke genelinde daha etkin bir şekilde uygulanmaya başlanan kalkınma planları ve yaşanan sanayileşme süreci etkili olmuştur. 1960-1965 periyodunda ise nüfus artış1 \% 1.71 gerçekleşmiş ve nüfus 650.191 kişiye yükselmiştir.

Zonguldak ilinde nüfus artışı dalgalanmalar şeklinde 1965-1990 döneminde de devam etmiştir. Yıllık nüfus artış hızı 1970'te \% 1.91, 1975'te \% 1.73, 1980'te \% 2.41, 1985 'te \% 1.79 ve 1990 'da \% 0.76 şeklinde geçekleşmiştir. 1980-1990 dönemi, Zonguldak ili açısından o ihtişamlı günlerin son dönemlerini oluşturmaktadır. Zonguldak, 1980-1985 döneminde artık göç veren il konumuna geçmiştir (Tandoğan, 1998:83). Bu dönemde ilde hemen her mahallede ocak vardiyası değişim saatlerinde eli ve yüzü kömür karası olmuş, başında 1şıklı bareti, elinde sefer tasları, yorgunluktan biraz eğilerek yürüyen ancak bir iş gününü daha siyah dünyadan aydınlık dünyaya sağ çıkmanın verdiği huzurla bitirmenin ve ailesine kavuşacak olmanın hissettirdiği mutluluk ile evine doğru yürüyen maden işçileri görülmekteydi. Her biri yorgun olmasına karşın karşılaştığı insanlara kömür karası 
yüzlerindeki tebessümle selam vermekteydi. Ancak bu görüntüler günümüzde birer hatıraya dönüşmektedir.

İlde nüfusun keskin şekilde azaldığı dönem 1990-1997 dönemi olmuştur. 1991 yılında Bartın ve 1995 yılında Karabük'ün ilden ayrılması ile 1997 yılında nüfus 1.073.560'tan 612.722'ye inmiştir.

Nüfus artış hızındaki dalgalanma 2000-2013 arasında da devam etmiştir. 2000 yılında 615.599 olan nüfus 2009 yılında 619.812'ye çıkmış ancak 2010 yılından itibaren nüfus kademeli şekilde azalarak 2013 yllında 601.567 kişiye inmiştir. Bu durumun en büyük nedeni, işsizliktir. TTK'nın işçi alımını minimuma indirmesi, yeni istihdam sahalarının yaratılmaması, TTK nedeniyle yaşamın pahalılığı ve emekli sayısının çok fazla olması diğer etkenlerdir. Böylece 2000'li yılların başından itibaren Zonguldak iç göç veren illerden biri durumuna düşmüştür.

\section{Zonguldak İl Nüfusunun Mekânsal Dağılışı}

Sahada nüfus dağılışını belirleyen faktörlerin başında yeryüzü şekilleri gelmektedir. Zonguldak ili arazisi, genel olarak Batı Karadeniz Dağlık Kuşağı içerisinde yer almakta olup, bu kuşağı oluşturan kıyı ve iç sıradağların birbirine oldukça yaklaştığı, hatta kesiştiği alanda bulunmaktadır. Bu kapsamda, dağlık ve parçalı bir topografik yapıya sahip olan sahada, yerleşim alanlarının dağılışında dağlar ve vadi sistemleri önemli bir belirleyici olmuştur. Buna göre, ilde genellikle kıyı kuşağındaki düz alanlar, akarsu vadileri ve bunların yüksek olmayan yamaçlarında yerleşmelerin ve dolayısıyla da nüfusun toplandığı gözlenmektedir. Ancak sahada dağlık alanların tamamıyla nüfustan yoksun alanlar olduğunu düşünmek de yanlış olur. İldeki yüksek kesimlerin hayvancilık faaliyetlerine bağlı olarak en azından mevsimlik olarak nüfus barındırdığı söylenebilir.

Karadeniz kıyı çizgisine paralel uzanan söz konusu bu dağlar, iklim koşulları açısından da belirgin farklılıklar oluşmasına neden olmaktadır. Kıyı kuşağı dağlarının denize bakan yamaçlarında, nemli ve ılıman iklim koşulları görülürken; iç kesimlere doğru bu koşullar tedrici bir şekilde etkisini yitirmektedir. Bu sebeple yaşama ve beşeri faaliyetlere daha uygun olan kıyı kesimin nüfus toplanma eğilimi göstermiş, iç kesimlerde ise benzer iklim şartlarının nispeten hissedildiği vadi içleri çoğunlukla tercih edilmiş̧ir.

Sahadaki yeryüzü şekillerinin diğer önemli bir etkisi, ulaşım faaliyetleri üzerinde görülmektedir. Kıyı ile iç kesimler arasındaki ulaşım ancak akarsu vadileri ve geçitler vasıtasıyla gerçekleşebilmektedir. Bu nedenle de, iç kesimlerde yer alan yerleşmelerin önemli bir kısmı, ulaşım koşullarının elverişli olduğu vadi içlerinde kurulmuştur. Gerek sahil yolu gerekse de iç kesimlere bağlanan yollar, fiziki coğrafya şartları nedeniyle eğimli, engebeli ve virajlıdır. Bu durum Zonguldak ile diğer iller arasındaki ulaşım süresinin artmasına neden olmaktadır. Söz konusu zaman sıkıntısını aşmak amacı ile il sınırlarına girişlerde tünel çalışmaları gerçekleştirilmiştir. Örneğin, Zonguldak ile Bolu Mengen sınırındaki 904 m'lik Dorukan Tüneli gibi.

Pek çok bilim insanı tarafından kent yerleşmeleri için 10.000 nüfus kriteri esas alınmaktadır. $\mathrm{Bu}$ açıdan ele alındığında 8 ilçe yerleşmesinin bu kritere uyduğu tespit edilmiştir (Tablo 2). İl bünyesindeki kentlerin coğrafi konumları göz önüne alındığında, 
nüfus yoğunluğunun kent yerleşmeleri arasında keskin şekilde değişmediği görülmektedir. En belirgin değişim, bölgenin en önemli limanı konumundaki Ereğli’de yaşanmaktadır. Ereğli kent nüfusu, Zonguldak Merkez ilçe nüfusundan daha fazladır. Diğer kentlerin nüfusları birbirlerine daha yakın dağılım göstermektedir (Tablo 2, Şekil 3). Bu konuda son çeyrek asırdır işsizlik sebebi ile merkezi yerlerdeki hızlı nüfus azalışı nedeniyle, merkezi yerler ile diğer yerleşmeler arasındaki nüfus farkının azalması etkilidir.

Tablo 2: Zonguldak İlindeki Kentler ve Nüfusları (2013)

\begin{tabular}{|l|c|c|}
\hline Kentler & Toplam Nüfus & İ Nüfusuna Oranı (\%) \\
\hline Merkez & 125.914 & 20.9 \\
\hline Alaplı & 44.668 & 7.4 \\
\hline Ereğli & 174.185 & 29 \\
\hline Devrek & 56.571 & 9.4 \\
\hline Çaycuma & 92.690 & 15.4 \\
\hline Gökçebey & 22.296 & 3.7 \\
\hline Kilimli & 40.789 & 6.8 \\
\hline Kozlu & 44.454 & 7.4 \\
\hline Toplam & 601.567 & 100 \\
\hline
\end{tabular}

Kaynak: ADNKS Verileri.

İl genelinde 182 olan aritmetik nüfus yoğunluğu, şüphesiz yüzölçümü değerlerinin de etkisi ile kıyı ilçelerinde nispeten daha fazladır (Tablo 3). İl genelindeki nüfus yoğunluklarının ilçelere göre dağılımı incelendiğinde genel olarak kıyı ilçelerinde (Merkez, Alaplı ve Ereğli) daha fazla olduğu görülmektedir. Yoğunluğun en fazla $\left(482 \mathrm{~km}^{2} / \mathrm{kişi}\right)$ olduğu yerleşme Çaycuma iken, en az (52) olduğu ise Kilimli'dir. Kilimli'nin 2013 yılı itibari ile yeni bir ilçe olması sebebi ile pek çok belde ve köy yerleşmesinin sınırları içerisine dahil edilmesi, yüzölçümünü çok fazla artırmış ve bu durum nüfus yoğunluğunun azalmasına yol açmıştır.

Tablo 3: Zonguldak İlindeki Kentler ve Nüfusları (2013)

\begin{tabular}{|l|c|c|c|}
\hline Kentler & Toplam Nüfus & Yüzölçümü $\left(\mathbf{k m}^{\mathbf{2}}\right)$ & $\begin{array}{l}\text { Nüfus Yoğunluğu } \\
\left(\mathbf{k m}^{\mathbf{2}} / \mathbf{k i s ̧ i}\right)\end{array}$ \\
\hline Merkez & 125.914 & 537 & 234 \\
\hline Alaplı & 44.668 & 185 & 241 \\
\hline Ereğli & 174.185 & 575 & 303 \\
\hline Devrek & 56.571 & 434 & 130 \\
\hline Çaycuma & 92.690 & 192 & 482 \\
\hline Gökçebey & 22.296 & 159 & 140 \\
\hline Kilimli & 40.789 & 784 & 52 \\
\hline Kozlu & 44.454 & 443 & 100 \\
\hline Toplam & 601.567 & 3309 & 182 \\
\hline
\end{tabular}

Kaynak: TÜİK Verilerinden Yararlanılarak Hesaplanmıştır. 


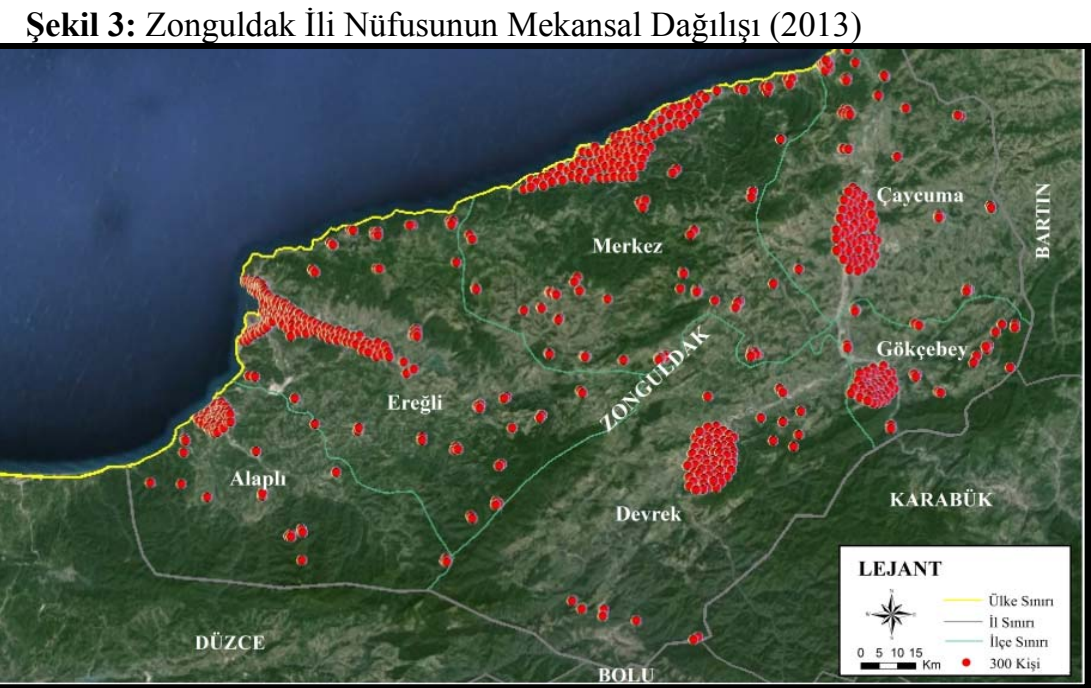

Kaynak: Google Earth Harita Tabanı Kullanılarak Hazırlanmıştır.

\section{Zonguldak İl Nüfusunun Cinsiyet Yapısı ve Cinsiyet Oranı}

Bir yerde yaşayan nüfus ile ilgili değişkenlerin başında yaş ve cinsiyet özellikleri gelmektedir. Ülkelere göre nüfusun yaş ve cinsiyet özellikleri farklılık gösterir. Yaş ve cinsiyet özelliklerinin sosyal ve ekonomik yansımaları olmaktadır. Çünkü farklı yaş ve cinsiyet grubundaki nüfusun işgücü, eğitim, sağlık ve tüketim gibi açılardan kapasite ve beklentileri farklıdır (Haupt \& Kane; 2004:5). Aynı şekilde ölümlerin - evlenme yaşının ve suç işleme oranının yaş ve cins dilimlerine dağılımı gibi veriler için de yaş ve cins dağılımlarının bilinmesi önem taşımaktadır (Doğanay ve diğerleri; 2001:54). Toplumun kadın - erkek nüfusundaki aşırı dengesizlik, özellikle doğum yapabilecek yaşlardaki kadın nüfusun azlığı, doğum oranının düşük olmasına yol açmaktadır. Aynı şekilde erkek nüfusun ekonomik yaşamda kadın nüfusa nazaran daha fazla görev aldığı göz önüne alındığında, kadın - erkek nüfusun çalışabilir nüfusa diğer bir ifade ile ekonominin insan gücü kaynaklarına etki ettiği de söylenebilir (Tandoğan, 1998:111).

Zonguldak'ta kadın - erkek nüfusları arasında çok büyük farklılıklar olmamakla beraber kadın nüfusun daha fazla olduğu göze çarpmaktadır (Tablo 4, Şekil 4). Kadın - erkek nüfusunda yaşanan bu değişimlerin en büyük sebebi, sosyo-ekonomik koşullar nedeniyle yaşanan göç olaylarıdır. Aradaki en büyük fark \% 5.6 ile 1927 yılında, en az fark ise \% 0.2 ile 1970 yılında yaşanmıştır.

1927 ve 1937 Nüfus Sayımları'nda kadın nüfus daha fazladır. 1927 yılında toplam nüfusun \% 52.8'i kadın iken \% 47.2'si erkektir. Nedeni ise uzun süren savaşlara bağlı olarak cumhuriyetin ilk yıllarında erkek nüfusta yaşanan azalmadır. Bu değerler 1935 yılı için sırası ile $\% 50.8$ ve $\% 49.2$ şeklindedir. Kadın nüfustaki fazlalık 1940-1965 dönemleri arasında yerini erkek nüfusun fazlalığına bırakmaktadır. Bu durumun nedeni, ilde gerçekleşen doğumlar ve ölümlerden ziyade nüfusun sosyo-ekonomik yapısında yaşanan değişimden 
kaynaklanmaktadır. Bu dönemlerde EKİnin çok fazla sayıda işçi alması nedeni ile Anadolu'nun büyük kesiminden Zonguldak'a erkek işçi göçü gerçekleşmiştir. Erkek nüfusun en fazla olduğu dönem 1955-1960 iken, kadın nüfus ise 2000-2007 döneminde zirveye ulaşmıştır.

Tablo 4: Zonguldak İlinde Erkek ve Kadın Nüfus Yüzdesi (1927 - 2013)

\begin{tabular}{|l|l|l|l|l|l|}
\hline $\begin{array}{l}\text { Sayım } \\
\text { Ylı }\end{array}$ & $\begin{array}{l}\text { Toplam } \\
\text { Nüfus }\end{array}$ & Erkek Nüfus & $\begin{array}{l}\text { Erkek } \\
\text { Nüfus } \\
\text { Yüzdesi }\end{array}$ & Kadın Nüfus & $\begin{array}{l}\text { Kadın } \\
\text { Nüfus } \\
\text { Yüzdesi }\end{array}$ \\
\hline $\mathbf{1 9 2 7}$ & 267.990 & 126.617 & 47.2 & 141.373 & 52.8 \\
\hline $\mathbf{1 9 3 5}$ & 322.108 & 158.508 & 49.2 & 163.600 & 50.8 \\
\hline $\mathbf{1 9 4 0}$ & 349.783 & 175.866 & 50.2 & 173.917 & 49.8 \\
\hline $\mathbf{1 9 4 5}$ & 383.481 & 199.005 & 51.8 & 184.476 & 48.2 \\
\hline $\mathbf{1 9 5 0}$ & 426.684 & 220.564 & 51.6 & 204.120 & 48.4 \\
\hline $\mathbf{1 9 5 5}$ & 491.147 & 251.292 & 51.1 & 239.855 & 48.9 \\
\hline $\mathbf{1 9 6 0}$ & 569.059 & 290.293 & 51 & 278.766 & 49 \\
\hline $\mathbf{1 9 6 5}$ & 650.191 & 326.918 & 50.2 & 323.273 & 49.8 \\
\hline $\mathbf{1 9 7 0}$ & 743.654 & 371.109 & 49.9 & 372.545 & 50.1 \\
\hline $\mathbf{1 9 7 5}$ & 836.617 & 426.668 & 50.9 & 409.488 & 49.1 \\
\hline $\mathbf{1 9 8 0}$ & 954.512 & 475.105 & 49.7 & 479.407 & 50.3 \\
\hline $\mathbf{1 9 8 5}$ & 1.044 .945 & 519.264 & 49.6 & 525.681 & 50.4 \\
\hline $\mathbf{1 9 9 0}$ & 1.073 .560 & 526.041 & 48.9 & 547.519 & 51.1 \\
\hline $\mathbf{1 9 9 7}$ & 612.722 & 302.415 & 49.3 & 310.307 & 50.7 \\
\hline $\mathbf{2 0 0 0}$ & 615.599 & 300.676 & 48.8 & 314.923 & 51.2 \\
\hline $\mathbf{2 0 0 7}$ & 615.890 & 302.827 & 49.1 & 313.063 & 50.9 \\
\hline $\mathbf{2 0 0 8}$ & 619.151 & 304.997 & 49.2 & 314.154 & 50.8 \\
\hline $\mathbf{2 0 0 9}$ & 619.812 & 306.075 & 49.3 & 313.737 & 50.7 \\
\hline $\mathbf{2 0 1 0}$ & 619.703 & 307.550 & 49.6 & 312.153 & 50.4 \\
\hline $\mathbf{2 0 1 1}$ & 612.406 & 302.370 & 49.3 & 310.036 & 50.7 \\
\hline $\mathbf{2 0 1 2}$ & 606.527 & 299.301 & 49.3 & 307.226 & 50.7 \\
\hline $\mathbf{2 0 1 3}$ & 601.567 & 296.910 & 49.3 & 304.657 & 50.7 \\
\hline $\mathbf{K a y}$ & 1016 & & & \\
\hline
\end{tabular}

Kaynak: TÜİK Nüfus Sayım Verileri.

1970’li yıllarda Avrupa'ya verilmeye başlanan işçi göçü bu kez erkek nüfusun azalmasına neden olmuştur. Özellikle Almanya, Hollanda ve Belçika başta olmak üzere pek çok AB ülkesine Zonguldak ilinin genelinden önemli ölçüde işçi göçü verilmiştir. Bu nedenle il toplam nüfus artışında da bir azalma görülmektedir. İl nüfusunda kadın nüfusundaki artı durum 1970-2013 arasında da devam etmiştir. Ancak kadın ve erkek nüfus arasındaki fark çok fazla açılmadan genellikle denge içerisinde sürmüştür. Bu durum üzerinde 1970'li yıllardan sonra il ve ilçe merkezlerindeki kamu kurum ve kuruluşlarında ağırlıklı olarak erkeklerin çalışmaya başlaması etkili olmuştur. 1990'lı yıllarda yüksek okul, fakülte ve üniversitenin açılması ile birlikte ile gerçekleşen öğrenci göçü, kadın ve erkek sayısındaki 
dengenin sürmesinde rol oynayan diğer bir etkendir. 2011, 2012 ve 2013 yılları itibari ile toplam nüfusun \% 50.3'ü kadın iken \% 49.7'si ise erkektir. Kilimli, Kozlu ve Çatalağzı gibi yerleşim birimlerinde çoğunlukla yatılı çalıştıkları için merkezlerde erkek sayısı buna karşın kırsal kesimlerde ise kadın sayısı daha fazladır.

Belirli bir nüfus içerisindeki 100 ya da 1000 kadın başına düşen erkek sayısı olarak tanımlanan cinsiyet oranının belirlenmesi önem arz eder. Her zaman için cinsiyet oranında kadın ya da erkek nüfustan birinin lehine bir durum söz konusudur. Doğum, ölüm, savaş, göç ve salgın hastalık gibi toplumsal olaylar cinsiyet oranı üzerinde etkili olmaktadır (Doğanay, 1997:164-165 ve Tümertekin ve Özgüç, 2011:272).

Şekil 4: Zonguldak İlinde Nüfusun Cinsiyete Göre Dağılımı (1927 - 2013)

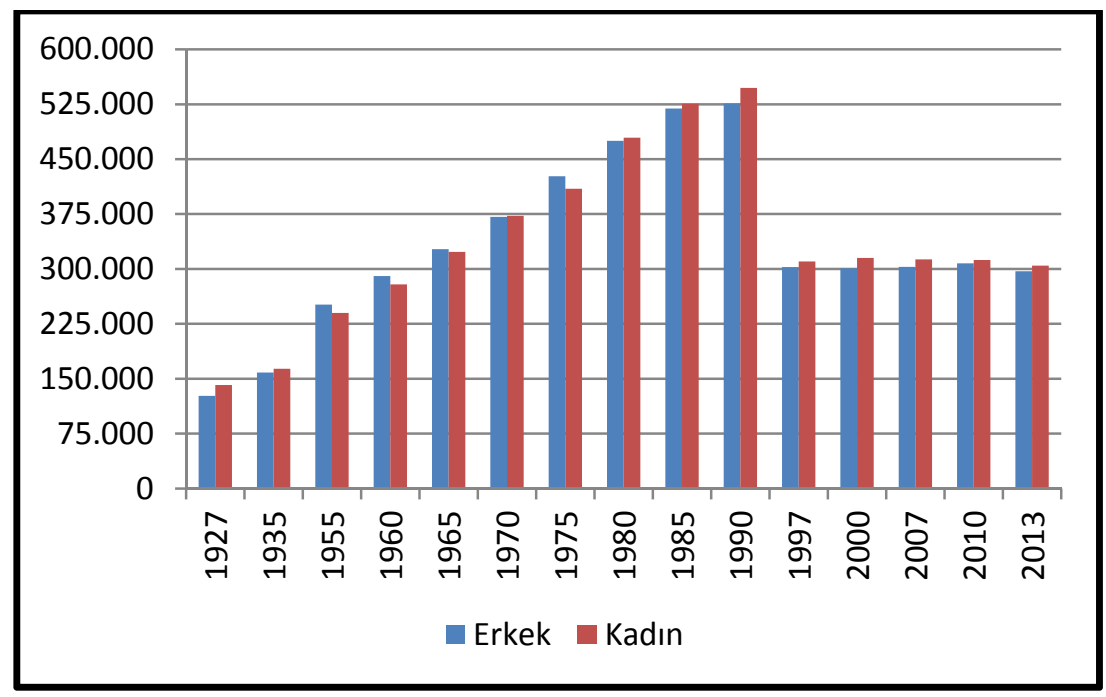

Kaynak: TÜiK Verilerinden Derlenerek Hesaplanmıştır.

Cinsiyet oranına bakıldığında ise en büyük farkın 1927 yılında, en az farkın ise 1955 yılında oluştuğu görülmektedir (Tablo 5). 2013 yılı itibari ile cinsiyet oranı Zonguldak için 97.4 iken bu oran Türkiye geneli iş̧̧in 101'dir (http://www.tuik.gov.tr).

Tablo 5'te kadın - erkek nüfusun yüzdeleri ile cinsiyet oranı yüzdeleri karşılaştırıldığı uyum görünmektedir. Cumhuriyetin ilk yıllarında erkek nüfusun savaşlar nedeniyle azalmasına bağlı olarak cinsiyet oranı azadır. Buna karşın yoğun işçi göçü alımının gerçekleştiği 1950-1965 döneminde cinsiyet oranı artış göstermiştir. Bu dönemin dışında ise cinsiyet oranı çoğunlukla kadın nüfus açısından dengede kalmıştır. 
Tablo 5: Zonguldak İlinde Nüfusun Cinsiyet Oranı (1927 - 2013)

\begin{tabular}{|l|l|l|l|}
\hline Sayım Yılı & Erkek Nüfus & Kadın Nüfus & Cinsiyet Oranı (\%) \\
\hline $\mathbf{1 9 2 7}$ & 126.617 & 141.373 & 89.5 \\
\hline $\mathbf{1 9 3 5}$ & 158.508 & 163.600 & 96.8 \\
\hline $\mathbf{1 9 4 0}$ & x & x & x \\
\hline $\mathbf{1 9 4 5}$ & x & x & x \\
\hline $\mathbf{1 9 5 0}$ & x & x & x \\
\hline $\mathbf{1 9 5 5}$ & 251.292 & 239.855 & 104.7 \\
\hline $\mathbf{1 9 6 0}$ & 290.293 & 278.766 & 104.1 \\
\hline $\mathbf{1 9 6 5}$ & 326.918 & 323.273 & 101.1 \\
\hline $\mathbf{1 9 7 0}$ & 371.109 & 372.545 & 99.6 \\
\hline $\mathbf{1 9 7 5}$ & 426.668 & 409.488 & 104.1 \\
\hline $\mathbf{1 9 8 0}$ & 475.105 & 479.407 & 99.1 \\
\hline $\mathbf{1 9 8 5}$ & 519.264 & 525.681 & 98.7 \\
\hline $\mathbf{1 9 9 0}$ & 526.041 & 547.519 & 96 \\
\hline $\mathbf{1 9 9 7}$ & 302.415 & 310.307 & 97.4 \\
\hline $\mathbf{2 0 0 0}$ & 300.676 & 314.923 & 95.4 \\
\hline $\mathbf{2 0 0 7}$ & 302.827 & 313.063 & 96.7 \\
\hline $\mathbf{2 0 0 8}$ & 304.997 & 314.154 & 97 \\
\hline $\mathbf{2 0 0 9}$ & 306.075 & 313.737 & 97.5 \\
\hline $\mathbf{2 0 1 0}$ & 307.550 & 312.153 & 98.5 \\
\hline $\mathbf{2 0 1 1}$ & 302.370 & 310.036 & 97.5 \\
\hline $\mathbf{2 0 1 2}$ & 299.301 & 307.226 & 97.4 \\
\hline $\mathbf{2 0 1 3}$ & 296.910 & 304.657 & 97.4 \\
\hline
\end{tabular}

Kaynak: TÜİK Genel Nüfus Sayımları ve ADNKS Verilerinden Derlenmiştir.

\section{Zonguldak İı Nüfusunun Doğum - Ölüm Oranları ve Yaş Yapısı}

Nüfus kitlesine ilişkin temel değişkenlerin başında, doğumlar ve ölümler gelmektedir. Doğumlar, nüfus artışını sağlayan en önemli unsurdur. Doğum ile ölüm arasındaki fark aynı zamanda doğal nüfus artı̧̧ ya da azalışını vermektedir. Belli bir yıldaki canlı doğum sayısının 15-49 yaş grubunun oluşturduğu doğurgan nüfusa bölünmesi ile elde edilen doğurganlık oranı aynı zamanda çocuk nüfusun fazla ya da az olduğunu ortaya koymaktadır. Valilik, kaymakamlık ve belediyeye bağl ilgili kurumlardan elde edilen veriler derlendiğinde Zonguldak'ta 2013 yllı itibari ile doğurganlık oranı \% 1.61'dir. $\quad \mathrm{Bu}$ oran 2013 yılı Türkiye ortalamasının (\% 2.09) altındadır. Söz konusu oran Zonguldak için 2009 yllinda \% 1.70, 2010 yllinda \% 1.64, 2011 yllında \% 1.57 ve 2012 yllında $\% 1.61$ iken, Türkiye için 2009 yılında \% 2.08, 2010 yllında \% 2.06, 2011 yllında \% 2.02 ve 2012 yılında $\% 2.08$ şeklinde gerçekleşmiştir. Bu durumun en önemli nedenleri; 2000'li yılların başından itibaren 15-49 yaş arasındaki doğurgan nüfusun göç hareketi sebebiyle başka illere yerleşmesi, geride yaşı nüfusun kalması nedeniyle yaş yapısına bağlı olarak kısmen de olsa doğurganlığın azalması ve şehirleşme süreci ile birlikte doğumlarda meydana gelen 
azalmadır. Bunun yanında sosyo-kültürel değişime bağlı olarak yeni neslin fazla çocuk sahibi olmak istememesi, yaşam koşulları nedeniyle evlenme çağındaki gençlerin çalışmak durumunda kalması ve üniversitede okuma oranının artması da etkilidir.

Nüfus değişimindeki diğer önemli kriter ise ölümlerdir. İlde genel ölüm oranı 2013 yılı itibari ile \%o 6.1'dir. Bu oran 2013 yılı Türkiye ortalamasının (\%o 5.1) üzerindedir. Bu durumu şu şekilde açıklayabiliriz. Zonguldak denilince akla kara elmas kömür ve neden olduğu sağlık sorunları gelmektedir. Özellikle doğrudan kömür üretiminde çalışan işçiler, akciğer ve kanser ile ilgili değişik rahatsızlıklara yakalanmaktadır. Zonguldak'ta kömür tozuna bağlı olarak ortaya çıkan meslek hastalığının çokça olduğu bilinmektedir. Bu nedenden dolayı cumhuriyetin ilk yıllarından itibaren Zonguldak'ta sağlık konusunda yatırımların fazla yapılmasına bağlı olarak çok sayıda hastane bulunmaktadır. Ancak bu durum yinede meslek hastalığına bağlı ölümleri engelleyememektedir. 50’li yaşlardan sonra meslek hastalığı erkek nüfusta kendisini hissettirmeye başlamaktadır.

Nüfusun temel ölçütlerinden biri de yaş yapısıdır. Nüfusun miktarı ve cinsellik oranı yanında çeşitli yaş gruplarının ve her yaş grubuna dağılmış nüfus miktarının bilinmesi, özellikle çalışabilir ve faal nüfus olarak adlandırılan 15-64 yaş arasındaki nüfus miktarlarının işgücü kapasitesi, gıda ve çeşitli hizmetlere olan ihtiyaç, aile tipleri doğum ve ölüm oranları, nüfusun dinamiklik ve ortalama ömrü ile son olarak mekânda yaşanan göçleri algılamak bakımından son derece önemlidir (Tümertekin, 1994:77). Özellikle sosyal ve ekonomik amaçlı planlamalarda stratejilerin isabetli seçilebilmesi bakımından nüfusun yaş yapısının analiz edilmesi nüfusun miktarı kadar önem arz eder (Doğanay, 1997:165).

Nüfusun yaş yapısı çeşitli eşik değerleri belirlenerek gruplandırılabilir. Nüfus 0-14, $15-64,65$ ve üzeri şeklinde geniş aralıklı yaş gruplarına ya da $0-4,5-9,10-14,15-19,20-24,25-$ $29, \ldots$ gibi dar aralıklı yaş gruplarına göre sınıflandırılabilir. Çocuk, yetişkin ya da yaşlı nüfus oranlarının bilinmesi, beslenme, eğitim, sağllk, konut ve istihdam gibi sosyo-ekonomik ve kültürel açıdan uygulanacak politikaların planlanması açısından önem taşımaktadır. Dar aralıklı gruplandırmada nüfusun hemen her yaş aralığına ait değerlendirme yapma olanağının yanında, geniş aralıklı gruplandırmada ise nüfusun faal ve bağımlılık durumu daha rahat ve anlaşılır olarak ortaya konulmaktadır. Nitekim geniş aralıklı gruplandırmada 15-64 yaş dilimleri arasındaki nüfus faal veya çalışabilir, diğer iki yaş dilimi $(0-14,65$ ve üzeri) arasındaki nüfus ise çalışmayan ya da bağımlı nüfus olarak kabul edilir (Doğanay, 1997:166) Bu nedenlerden dolayı Zonguldak il nüfusuna ait dar aralıklı ve geniş aralıklı sınıflandırmalar analiz edilmiştir.

İl nüfusunun dar aralıklı yaş gruplandırılmasında, geniş aralıklı yaş gruplandırılmasına uygun olarak çocuk ve yetişkin nüfusa ait kısım daha fazla yer kaplamaktadır (Şekil 5). Yığılmanın 25-49 yaş aralığında olduğu görülmektedir. Bu durum iş isteyen çok sayıda çalışma çağındaki nüfusun varlığını ortaya koymaktadır. 60 yaş ve üzeri gurupta ise belirtildiği üzere erkek nüfusta meslek hastalıkları nedeniyle hızlı azalma yaşanmaktadır. En fazla 30-34 yaş grubunda, en az ise 85 ve üzeri yaş grubunda nüfus bulunmaktadır. Dağılım göz önüne alındığında aşağıdan yukarıya doğru genel olarak artan nüfus miktarı 30-34 yaş diliminden sonra düşüş eğilimine girmektedir. Buradan iki sonuç çıkarabiliriz. İlki, askerden dönmüş nüfusun iş imkânı bulana kadar ya da evlenme çağı 
gelmiş erkek nüfusun bu iki sorunu çözene kadar ailesinin yanında kalarak göç hareketine katılmadıklarıdır. İkincisi ise bu yaştan sonra iş ve evlenme durumlarını çözen erkek ve kadın nüfusun yaşam koşulları nedeni ile fazla çocuk istememeleri sonucunda doğum oranının azalmaya başlamasıdır. Ayrıca bu yaş grubunda ve sonrasında yer alan kadın nüfusun fazla olması, göç olayını erkek nüfusun geçekleştirdiğini göstermektedir. 55-59 yaş grubuna kadar olan diğer gruplarda da kadın nüfus fazlalığı dikkat çekmektedir. 55-59 yaş grubunda erkek nüfus fazlalığı görülmektedir. Bu yaşlarda görülen erkek nüfus fazlalığı, genellikle ilçedeki çeşitli kuruluşlardan emekli olmuş nüfustan kaynaklanır. 55-59 yas grubundan soma kadıların lehine bir gelişme göstermektedir. Bu durum, kuskusuz göçlerin yoğun olduğu 1950 'h yıllarda bu harekete katılan erkeklerin ön planda olmasının yanında, ülkemizin genelinde olduğu gibi kadınlarda ortalama insan ömrünün daha fazla olmasının da bir sonucudur. Son olarak en üst kısımda yer alan 65 ve daha yukarı yaş grubunda görülen genişleme, bunu açıkça ortaya koymaktadır.

Şekil 5: Zonguldak İli Nüfusunun Dar Aralıklı Gruplandırmaya Göre Dağılımı (2013)

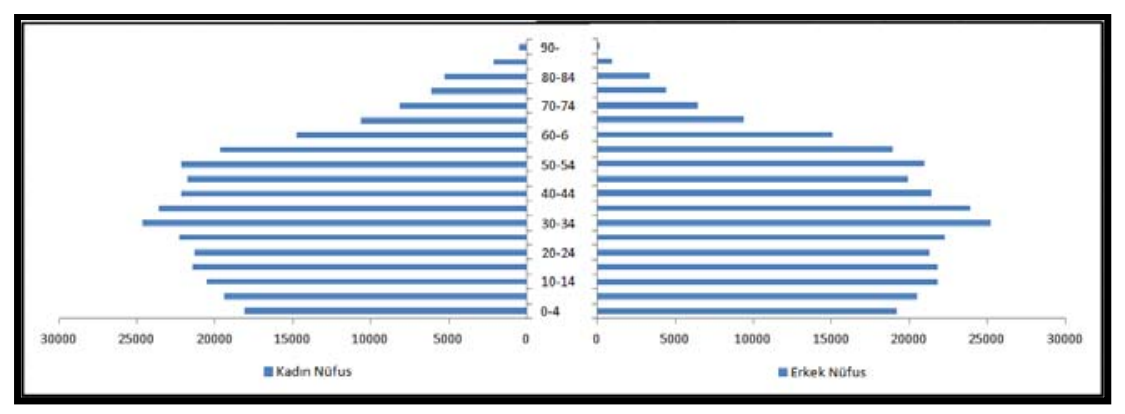

Kaynak: ADNKS Verilerinden Derlenmiştir.

Geniş aralıklı gruplandırmaya göre Zonguldak il nüfusunun \% 22.1'i 0-14 yaş grubunda bulunmaktadır (Şekil 6). Ülke genelinde ise bu oran \% 24.6'dır. Bu durum ildeki doğum oranının az olduğunu göstermektedir. Çalışma çağındaki nüfus olarak da adlandırılan 15-64 yaş grubu ise toplam il nüfusunun \% 69.7'sini oluşturmaktadır. Bu oran ülke genelinde ise \% 67.7'dir. Ancak il genelindeki işsizlik sorunu nedeni ile bu yaş grubundaki nüfusun büyük kısmı işsiz durumda ve göç etmektedir. Zonguldak’taki yaşlı nüfus oranı (\% 8.2) ise nispeten yüksektir. Bu durumun temel nedeni ise genç nüfusun göç ederken ardında erken yaşta emekli olmuş emekli nüfusu bırakmalardır. Yaşlı nüfusun fazlalığı, Zonguldak ilinin "emekliler şehri" olarak ifade edilmesine neden olmaktadır. Bu bakımdan nüfus içerisinde yaşlı nüfusun payı arttıkça önümüzdeki dönemde bu yaş grubuna yönelik sağlık ve sosyal güvenlik hizmetlerinin yeniden ele alınması gerekmektedir (Başıbüyük, 2005:8). 2013 yılı itibari ile bu oran Türkiye için \% 7.7'dir (http://www.tuik.gov.tr).

Zonguldak il nüfusunun cinsiyete göre geniş aralıklı gruplandırılması göz önüne alındığında; erkek nüfusun \% 10,2'si 0-14 (61.547 kişi), \% 35'i 15-64 (210.745 kişi) ve 4,1'i 65 ve üzeri (24.618 kişi) yaş gurubunda bulunmaktadır. Buna karşın kadın nüfusun \% 9,6's1 0-14 (58.059), \% 3,6's1 15-64 (213.901) ve \% 5,5'i 65 ve üzeri (32.737 kişi) yaş gurubunda yer almaktadır (Şekil 3). 
Geniş aralıklı gruplandırma, nüfusun bağımlılık oranının hesaplanmasında da kullanılabilir. Çalışma çağı dışındaki nüfusun $\quad$ (0-14 ve 65+), çalışma çağı içerisindeki nüfusa (15-64) oranlanması sonucu elde edilen bu oran, 2013 yılı için Zonguldak’ta yaklaşık \% 42 iken, Türkiye genelinde yaklaşık \% 48.0 olarak gerçekleşmiştir. Buna göre, araştırma sahasındaki değerlerin, ülkemiz genelinden düşük olduğu görülmektedir. Bunun temel nedenleri; Zonguldak’ta doğurganlık oranının (\% 1.61) Türkiye ortalamasının altında olması sebebi ile aktif nüfusun az olmasıdır.

Şekil 6: Zonguldak İli Nüfusunun Geniş Aralıklı Gruplandırmaya Göre Dağılımı (2013)

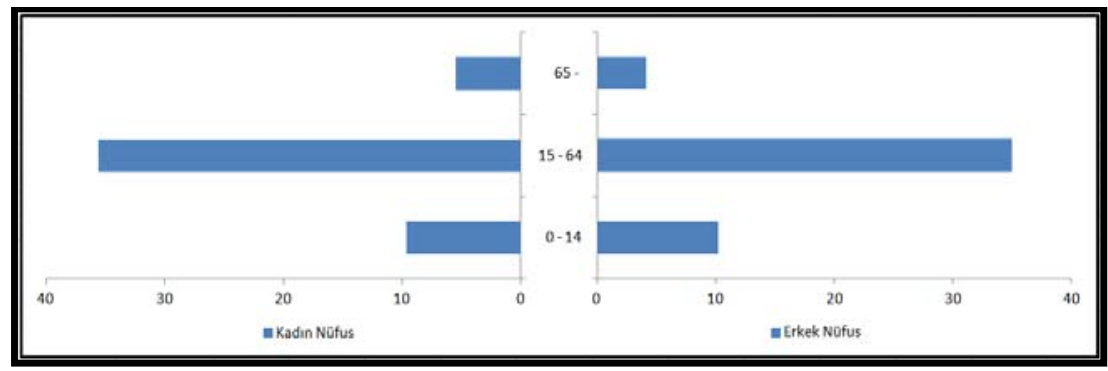

Kaynak: ADNKS Verilerinden Derlenmiştir.

\section{Göçler}

Gerek nüfusun yapısı ve dağılışı üzerinde belirleyici olması gerekse de neden ve sonuçları itibariyle göç olgusu, coğrafyanın da öncelikli inceleme alanlarından biridir. Nüfusun devamlı yaşam bölgelerini kişisel, aileler ve gruplar halinde terk edip, geçici ya da sürekli olarak yaşamak amacıyla bir başka yere gitmesi (Doğanay, 1997: 172-173) şeklinde tanımlanabilecek olan göç; göç alınan ve verilen mekan açısından bir taraftan nedenleri diğer taraftan da sonuçları itibariyle önem taşıyan bir olgudur.

Genellikle ekonomik nedenlerden dolayı gerçekleşen göçler, belirli bir sahadaki nüfusun miktarı ve demografik yapısında önemli değişimlere neden olabilmektedir. Zonguldak, işsizliğe bağlı geçim sıkıntısı nedeniyle çok fazla göç veren bir ildir. Oysaki aynı Zonguldak 1950-1980'li yıllar arasında yoğun işçi göçü almış bir sanayi şehri durumunda idi. Ancak uygulanan yanlış politikalar, sadece sanayi ağırlıklı bir ekonomik planlamaya gidilmesi, tarım ve hizmet sektörlerinin geliştirilmemesi, yeni istihdam sahalarının yaratılamaması ve geçim sıkıntısının doğması gibi faktörler ile insanlar 2000'lerden sonra Zonguldak'ı terk etmeye başlamıştır.

Günümüzde iç göç vermesi ile bilinen Zonguldak aynı zamanda 1960-1975 yılları arasında Almanya, Hollanda, Fransa, Avusturya ve Belçika başta olmak üzere pek Avrupa ülkesine de işçi göçü vermiştir. Yurt dışına göçlerin temel sebebi, ekonomik güçlüklerdir. Yani artan çalışma çağındaki nüfusa, yurt içinde yeterli istihdam alanlar açamayıştan ileri gelir. Bu sorun yanında, uygun ücret şartlan, sosyal güvenlik avantajları, bir batı ülkesinde çalışmayı ve öğrenim görmeyi bir arada sürdürmek, çok kazanma isteği gibi faktörler de kuşkusuz bu harekette etkili olmuştur (Ertürk ve diğerleri, 2000:253). 
Zonguldak ili, bulunduğu bölge ile aynı kaderi paylaşmakta olup, göç veren yerleşmeler arasında kendisine yer bulmuştur (Tablo 6). 1980-1985 döneminde 47.770 kişi ve 1985-1990 arasında 68.311 kişi Zonguldak’tan ülkemizin değişik yerlerine göç etmişken, sırası ile 29.219 ve 38.943 kişi de göç yoluyla ile gelmiştir. Yani, söz konusu devrede yaşanan net göçler -18.551 ve -29.368 iken, net göç hızı da $\%$-20 ve \%o -29. 4olarak karşımıza çıkmıştır.

Net göçün zirve yaptığı dönem ise Karabük ilçesinin il olarak ayrılması ile birlikte fabrikada çalışan ancak yaşamlarını Zonguldak ilinde sürdüren vatandaşların Karabük’e göç etmesidir. 2007-2013 devresinde ise toplamda 135.414 kişi Zonguldak’tan göç etmişken; ilin aldığı göç miktarı da 96.716 kişidir. Buna göre, adı geçen devrede yaşanan net göç -38.698 olmuştur. 2007 yılı sonrası net göçün negatif yönde sürekli arttığı görülmektedir.

Tablo 6: Zonguldak İlinin Yıllara Göre Verdiği Aldığı ve Verdiği Göç Miktarı (1980 - 2013)

\begin{tabular}{|l|l|l|l|l|}
\hline Yıllar & Aldığı Göç & Verdiği Göç & Net Göç & $\begin{array}{l}\text { Net Göç Hızı } \\
(\mathbf{\%} 0)\end{array}$ \\
\hline $\mathbf{1 9 8 0}-\mathbf{1 9 8 5}$ & 29.219 & 47.770 & -18.551 & -20 \\
\hline $\mathbf{1 9 8 5}-\mathbf{1 9 9 0}$ & 38.943 & 68.311 & -29.368 & -29.4 \\
\hline $\mathbf{1 9 9 5}-\mathbf{2 0 0 0}$ & 27.839 & 71.848 & -44.009 & -73.8 \\
\hline $\mathbf{2 0 0 7}-\mathbf{2 0 0 8}$ & 17.639 & 19.530 & -1.891 & -3.1 \\
\hline $\mathbf{2 0 0 8}-\mathbf{2 0 0 9}$ & 16.258 & 20.701 & -4.443 & -7.1 \\
\hline $\mathbf{2 0 0 9}-\mathbf{2 0 1 0}$ & 15.712 & 23.267 & -7.555 & -12.1 \\
\hline $\mathbf{2 0 1 0}-\mathbf{2 0 1 1}$ & 15.822 & 23.658 & -7.836 & -12.7 \\
\hline $\mathbf{2 0 1 1}-\mathbf{2 0 1 2}$ & 14.279 & 22.687 & -8.408 & -13.8 \\
\hline $\mathbf{2 0 1 2}-\mathbf{2 0 1 3}$ & 17.006 & 25.571 & -8.565 & -14.1 \\
\hline
\end{tabular}

Kaynak: TÜİK Göç İstatistikleri ve ADNKS verilerinden derlenmiştir.

\section{Sonuç ve Öneriler}

Cumhuriyetin ilk yıllarından itibaren il yönetim birimi olan Zonguldak'ın nüfusu, ilk genel nüfus sayımının yapıldığg 1927 yılından 1990 nüfus sayımına kadar sürekli artış göstermiştir. Nitekim 1927 y1lında il nüfusu 267.990 iken bu sayı 1990 y1lında 1.073.560'a yükselmiştir. Diğer bir ifade ile nüfus 63 yılda \% 400‘lük yüksek bir artış göstererek Türkiye nüfusunun artış değerine (\% 413.7) yaklaşmıştır (Bulut, 2000:19). Bu durumun temel nedeni, özellikle 1950'li yıllardan sonra alınan işçi göçleridir. Ancak Bartın ve Karabük illerinin ayrılması ile nüfus yaklaşık \% 40 azalma göstererek 600.000 düzeyine inmiștir. 2000'li yıllardan sonra ise nüfus artış hızı azalmaya başlamış ve bu azalış 2010 yılından itibaren yerini sert şekilde düşmeye bırakmıştır. 2010-2013 yılları arasındaki 4 yıllık kısa süre toplamda \% 2.93'lik azalma yaşanmıştır. Bu durum üzerinde işsizliğe bağlı olarak iç göç verilmesi temel faktördür.

Zonguldak'ta doğurganlık oranının Türkiye genelinden düşük olduğu görülmektedir. Bu durumun temel nedenleri 2000 yılı sonrasında 15-49 yaş arasındaki doğurgan nüfusun göç hareketi sebebiyle başka illere yerleşmesi, sosyo-kültürel değişime bağlı olarak yeni neslin ikiden fazla çocuk sahibi olmak istememesi, yaşam koşulları 
nedeniyle evlenme çağındaki gençlerin çalışmak durumunda kalması ve üniversitede okuma oranının artması da etkilidir. İlde genel ölüm oranı 2013 yılı itibari ile \%o 6.1'dir ve bu oran Türkiye ortalamasının (\% 5.1) üzerindedir. Bu durumun nedeni ise kömürün neden olduğu sağlık sorunlarıdır.

İl nüfusunun cinsiyete göre dağılımına bakıldığında 1927 yılından günümüze dek erkek ve kadın nüfusunun oranlarında çoğunlukla kadın nüfus lehine bir dağılım gerçekleşmiştir. Yoğun iş̧̧i göçü alınan 1950 - 1970 dönemi dışında kadın nüfus her dönem fazla olmuştur.

Zonguldak'ta cinsiyet oranı ise 1980'li yıllara kadar sosyo-ekonomik ve göçler nedeniyle sürekli değiş̧im göstermesine karşın bu yıllardan itibaren daha sabit bir duruma gelmiştir.

İl nüfusunun yaş gruplarına göre dağılımına bakıldığında çalışma çağı ve çocuk nüfusun fazla olduğu ve yaşlı nüfusun ise az olduğu görülmektedir. Yığılma çalışma yaşı grubundadır. Ancak yeterli istihdamın olmaması nedeniyle çalışma çağındaki nüfus son yıllarda göç etmektedir. Bu durum il ekonomisinin mevcut ve gelecekteki ekonomik yapısı açısından olumsuzdur. Bu nedenle göçü durduracak ya da yavaşlatacak düzeyde yeni iş alanlarının oluşturulması gerekmektedir. Yaşlı nüfusun az olmasında meslek hastalıklarına bağlı erken yaşta ölümler önemli rol oynamaktadır.

Zonguldak'ta görülen ve önemli sosyal sorunlara yol açan göç hareketinin önlenmesi ve en azından nüfusun dengede tutulması amaciyla, öncelikle sahada istihdam şartlarını artıııcı önlemlerin alınması gerekmektedir. Bu amaçla Zonguldak'a yatırımların çekilmesi ve bu yatırımların korunabilmesi için ilgili kurum ve kuruluşların sürekli sadece kâğıt üzerinde kalan stratejiler belirlemesi değil derhal yaşama geçecek uygulamalar gerçekleştirmeleri gerekmektedir. İş imkânlarının sadece taş kömürü ve tali uzantılarına bağlı kılınması önlenmeli, tarım ve hayvancılığın kırsal alanlarda modernize edilerek yaygınlaştırılması, üniversite - kent iş birliğinin sağlanması zorunludur. Gerekli önlemlerin alınarak Zonguldak ilinin 1980 ve 1990'lı yıllardaki sosyo-ekonomik ve kültürel düzeyine ulaşması umut edilmektedir.

Nüfusun mekânsal dağılışı göz önüne alındığında yaşam ve ekonomik faaliyetlere uygun olan kıyı kesimler ile iç kesimlerde vadi içleri ve ova niteliğindeki düzlüklere nüfusun daha fazla olduğu görülmektedir. Bu durum yer şekillerinin nüfusun mekânsal ağılışı üzerindeki etkisini ortaya koymaktadır.

\section{KAYNAKÇA}

ARIBAŞ, Kenan ve ÖCAL, Tülay, (2007), Bucak İlçesinin Nüfus Coğrafyası, Doğu Coğrafya Dergisi, Sayı 17, s. 309-344.

BAŞIBÜYÜK, Âdem, (2005), Doğu Anadolu Bölgesi'nde Nüfusun Cinsiyet ve Yaş Yapısl, Doğu Coğrafya Dergisi, Sayı: 14, s. 67-95. BULUT, İhsan, (2000), Yozgat'ın Nüfus Coğrafyası Özellikleri, Doğu Coğrafya Dergisi, Sayı 4, S. 19-54. 
Devlet İstatistik Enstitüsü, (1927), Genel Nüfus Sayımı, İstatistik Genel Direktörlügü.

TC Başbakanlık

Devlet İstatistik Enstitüsü, (1935)-(1940)-(1945)-(1950)-(1955)-(1960)-(1965)-(1970)(1975)-(1980)-(1985)-(1990)-(2000) Genel Nüfus Sayımı, TC Başbakanlık İstatistik Genel Direktörlüğü.

Türkiye İstatistik Enstitüsü, (2007)-(2008)-(2009)-(2010)-(2011)-(2012)-(2013) Adrese Dayalı Nüfus Kayıt Sistemi Nüfus Sayımı.

DOĞANAY, Hayati, (1991), Demografya, Atatürk Üniversitesi Kazım Karabekir Eğitim Fakültesi, Erzurum.

DOĞANAY, Hayati, (1997), Türkiye Beşeri Coğrafyası, MEB Yay. No: 2982, Bilim ve Kültür Eserleri Dizisi No: 877, Eğitim Dizisi No: 10, s. 165-166, İstanbul.

DOĞANAY, Hayati, Orhan, Fatih, (2014), Artvin İlinde Nüfusun Başlıca Özellikleri, Doğu Coğrafya Dergisi, Sayı 31, s. 1-22, Erzurum.

EMİOĞLU, Mecdi, (1966), Türkiye'de Yaşlı Nüfusun Artışı ve Coğrafi Dağılım Özellikleri, Coğrafya Araştırmaları Dergisi, Sayı 11, s. 25-49.

ERTÜRK, Mustafa., YAZICI, Hakkı, BAŞIBÜYÜK, Adem, (2000), İskilip İlçesinin Demografik Özellikleri, Doğu Coğrafya Dergisi, Sayı 4, s. 237-272.

GENÇ, Hamdi, (2010), Cumhuriyetin İlk Ylllarında Zonguldak'ta Nüfus, Ticaret ve Sanayi (1920-1932), Zonguldak Karaelmas Üniversitesi Sosyal Bilimler Dergisi, Cilt 6, Say1 122, s. 137-152.

HAUPT, A. \& KANE, T. T., (2004), 2004 Population Handbook, Population Reference Bureau's, Washington, s. 5.

İLHAN, M. Hamdi ve KOÇAL, Ali, (1986), İki Katl Ş̧ehir Zonguldak.

KARAKUYU, Mehmet, (2007), Alaşehir İlçesinin Nüfus Gelişimi, Doğu Coğrafya Dergisi, Sayı 17, s. 137-161, Erzurum.

KAYA, Faruk, (2013), Ağrı İli’nin 1927-2012 Sayım Dönemleri Kır-kent Nüfus Hareketleri, The Journal of Academic Socail Science Studies, p. 535-559.

SÖNMEZ, Mehmet Emin, (2010), Muș İlinde Nüfus Hareketlerinin Nedenleri ve Sonuçları, Türk Coğrafya Dergisi, Sayı 55, s. 54-57, İstanbul.

ŞAHIN, Salih, (2007), Geçmiş, Günümüz ve Gelecekte Nüfus Gerçeği, Gazi Kitabevi, Ankara, s. 14-15.

TANDOĞAN, Ahmet, (1998), Demografik Temel Kavramlar ve Türkiye Nüfusu, Lega Kitabevi, Trabzon.

TANOĞLU, Ali, (1966), Nüfus ve Yerleşme, İstanbul Üniversitesi Yayınları, No:1183, Edebiyat Fakültesi Coğrafya Enstitüsü Yayınları, No: 45, İstanbul. 
Zonguldak İlinde Nüfusun Gelişsimi ve Dă̆ı̆llı̧ı

TÜMERTEKINN, Erol, (1994), Beşeri Coğrafyaya Giriş, İstanbul Üniversitesi Yay. No: 3819, Edebiyat Fak. Yay. No:246, İstanbul, s. 177.

TÜMERTEKİN, Erol ve ÖZGÜÇ, Nazmiye, (2011), Beşeri Coğrafya: İnsan-Kültür-Mekân, Çantay Kitabevi, İstanbul.

YAVUZ, Orhan, (1994), Erzurum'dan Göç Sorunu, Nedenleri, Sonuçları ve Çözüm Yolları, Tarım Ekonomisi Dergisi, s. 10-21.

YENI, Ercan; KURU, Funda GÜRLEYEN, vd., (2013), Zonguldak Doğa Turizmi Gelişme Planı, TC Orman ve Su İşleri Bakanlığı Doğa Koruma ve Milli Parklar Müdürlüğü Basımı, Ankara.

ZAMAN, Serhat ve COŞKUN, Ogün, (2008), Rize İlinin Nüfus Coğrafyası Özellikleri ve Bunları Etkileyen Etmenler Üzerine Bir İnceleme, Atatürk Üniversitesi Sosyal Bilimler Enstitüsü Dergisi, Cilt 12, Sayı 2, Erzurum.

Zonguldak Valiliği Çevre ve Şehircilik İl Müdürlüğü, Zonguldak Il Çevre Durum Raporu 2011.

\section{Internet Siteleri}

http://www.zonguldak.gov.tr/default_b0.aspx?content=1036 erişim tarihi: 16.01.2014

http://www.tuik.gov.tr/HbGetirHTML.do?id=15974 erişim tarihi: 15.01.2014

http://www.tuik.gov.tr/PreTablo.do?alt_id=1068 erişim tarihi: 09.02.2014 